\title{
Combining experimental and mathematical modeling to reveal mechanisms of macrophage- dependent left ventricular remodeling
}

\author{
Yu-Fang Jin ${ }^{1 *}$, Hai- Chao Han², Jamie Berger ${ }^{3}$, Qiuxia Dai ${ }^{3}$ and Merry L Lindsey ${ }^{3}$
}

\begin{abstract}
Background: Progressive remodeling of the left ventricle (LV) following myocardial infarction (MI) can lead to congestive heart failure, but the underlying initiation factors remain poorly defined. The objective of this study, accordingly, was to determine the key factors and elucidate the regulatory mechanisms of LV remodeling using integrated computational and experimental approaches.

Results: By examining the extracellular matrix (ECM) gene expression and plasma analyte levels in C57/BL6J mice LV post-MI and ECM gene responses to transforming growth factor (TGF- $\beta_{1}$ ) in cultured cardiac fibroblasts, we found that key factors in LV remodeling included macrophages, fibroblasts, transforming growth factor- $\beta_{1}$, matrix metalloproteinase-9 (MMP-9), and specific collagen subtypes. We established a mathematical model to study LV remodeling post-MI by quantifying the dynamic balance between ECM construction and destruction. The mathematical model incorporated the key factors and demonstrated that TGF- $\beta_{1}$ stimuli and MMP-9 interventions with different strengths and intervention times lead to different LV remodeling outcomes. The predictions of the mathematical model fell within the range of experimental measurements for these interventions, providing validation for the model.

Conclusions: In conclusion, our results demonstrated that the balance between ECM synthesis and degradation, controlled by interactions of specific key factors, determines the LV remodeling outcomes. Our mathematical model, based on the balance between ECM construction and destruction, provides a useful tool for studying the regulatory mechanisms and for predicting LV remodeling outcomes.
\end{abstract}

\section{Background}

Myocardial infarction (MI) is a leading cause of congestive heart failure (CHF) [1,2]. In response to the MI stimulus, the left ventricle (LV) undergoes structural and functional adaptations that collectively have been termed as LV remodeling [3]. Adverse LV remodeling progresses to $\mathrm{CHF}$ in about $25 \%$ of post-MI patients, but the mechanisms that drive this progression remain poorly understood. During LV remodeling, both extracellular matrix (ECM) degradation and synthesis increase [4]. When ECM degradation dominates over synthesis, LV rupture can occur. When ECM synthesis dominates over degradation rates, fibrosis can occur.

\footnotetext{
* Correspondence: yufang.jin@utsa.edu

'Department of Electrical and Computer Engineering, University of Texas at San Antonio, San Antonio, USA

Full list of author information is available at the end of the article
}

Fibrosis increases myocardial stiffness and further depresses LV function to culminate in CHF $[5,6]$. Therefore, understanding what regulates the balance between ECM degradation and synthesis post-MI is critical to understand the mechanisms of LV remodeling and may allow us to target specific early diagnostic indicators to better guide treatment protocols.

Previous studies have shown that matrix metalloproteinases (MMPs) regulate ECM degradation and fibroblasts regulate ECM synthesis [7-9]. MMP-9, transforming growth factor- $\beta_{1}$ (TGF- $\left.\beta_{1}\right)$, tissue inhibitor of metalloproteinase-1 (TIMP-1), and collagen I levels are significantly elevated from day 1 to day 7 post-MI $[4,10,11]$. These increases are concomitant with increased infiltration of macrophages and activation of fibroblasts [12]. LV remodeling is a complex process that involves the spatiotemporal interactions among
C Biomed Central

(ㄷ) 2011 Jin et al; licensee BioMed Central Ltd. This is an Open Access article distributed under the terms of the Creative Commons Attribution License (http://creativecommons.org/licenses/by/2.0), which permits unrestricted use, distribution, and reproduction in any medium, provided the original work is properly cited. 
many biological components that remains poorly understood, in part due to the lack of complete sets of experimental data and computational models. Therefore, the objectives of this study were to 1 ) identify candidate biomarkers of LV remodeling post-MI from ECM gene expression and plasma analyte analyses, and 2) establish a mathematical model that incorporates experimental results to predict LV remodeling outcomes following different interventions. This model would provide a tool to elucidate LV regulatory mechanisms, estimate unmeasurable variables, and predict outcomes following multiple therapeutic scenarios.

\section{Results}

\section{Identifying Key Factors}

The key factors were pre-targeted by examining the most significant changes in ECM gene expression in the infarct region at day 7 post-MI, compared to gene expression in the remote non-infarcted region of the same LV and in the LV from control group. In the ECM gene array analysis, total RNA yield was $1.0 \pm 0.1$, $1.9 \pm 0.2$, and $2.9 \pm 0.3 \mu \mathrm{g} / \mathrm{mg} \mathrm{LV}$ tissue for control, remote, and infarct samples, respectively ( $<0.05$ for control vs remote and infarct, and for remote vs infarct). Of the 84 genes examined, 51 genes were differentially expressed among control, remote, and infarcted groups (all $\mathrm{p}<0.05$ ). The most prevalent pattern of gene expression changes was an increased expression level in the infarct tissue, compared to both control and remote groups. Of the 51 genes, 17 genes showed $>2.5$-fold change in the infarct region, and these genes are listed in Table 1 . Of the 17 genes with $>2.5$-fold change, the most significantly over expressed genes are cadherin 3 , collagen 1, collagen 2, and collagen 3, osteopontin, periostin, tissue inhibitor of metalloproteinase-1, fibronectin, secreted protein acidic and rich in cysteine (SPARC), and transforming growth factor- $\beta$. From this list, collagen I was selected as a key factor, because it is the major collagen in the normal LV, accounting for $90 \%$ of cardiac ECM. Osteopontin expression levels increased 206-fold in the infarct region compared to the control group, suggesting strong macrophage activation at day 7 post-MI. TIMP-1 expressions increased 31 -fold in the infarct compared to the control group, suggesting strong inhibition of proteolytic activity. Periostin gene expression level was increased 5.5 -fold, and TGF- $\beta 1$ gene expression level was increased 2.6-fold in the infarct sample at day 7 , suggesting significant fibroblast functions post-MI [13-16].

We further examined plasma profiles at day 7 post-MI to determine if gene level changes were mirrored in the post-MI plasma. In the plasma profiles, 11 proteins increased in the day 7 post-MI samples (Table 2). Of these, increased MMP-9 and TIMP-1 indicate changes
Table 1 ECM Gene Array (Data are Mean \pm SD normalized levels.)

\begin{tabular}{llll}
\hline Gene & Control & Remote & Infarct \\
\hline Cdh3 & $1.0 \mathrm{E}-05 \pm 9.8 \mathrm{E}-06$ & $7.4 \mathrm{E}-05 \pm 5.5 \mathrm{E}-05$ & $2.8 \mathrm{E}-04 \pm 1.3 \mathrm{E}-04$ \\
\hline Col1a1 & $1.5 \mathrm{E}-02 \pm 2.6 \mathrm{E}-03$ & $1.9 \mathrm{E}-01 \pm 1.0 \mathrm{E}-01$ & $8.2 \mathrm{E}-01 \pm 3.4 \mathrm{E}-01$ \\
\hline Col2a1 & $3.1 \mathrm{E}-06 \pm 6.3 \mathrm{E}-07$ & $1.1 \mathrm{E}-05 \pm 1.1 \mathrm{E}-05$ & $2.3 \mathrm{E}-04 \pm 1.8 \mathrm{E}-04$ \\
\hline Col3a1 & $5.0 \mathrm{E}-03 \pm 1.5 \mathrm{E}-03$ & $8.0 \mathrm{E}-02 \pm 5.5 \mathrm{E}-02$ & $2.3 \mathrm{E}-01 \pm 9.7 \mathrm{E}-02$ \\
\hline Col5a1 & $8.0 \mathrm{E}-3 \pm 2.0 \mathrm{E}-3$ & $2.3 \mathrm{E}-2 \pm 1.1 \mathrm{E}-2$ & $4.1 \mathrm{E}-2 \pm 1.6 \mathrm{E}-2$ \\
\hline Ctgf & $2.5 \mathrm{E}-02 \pm 4.3 \mathrm{E}-03$ & $7.6 \mathrm{E}-02 \pm 5.0 \mathrm{E}-02$ & $1.7 \mathrm{E}-01 \pm 9.1 \mathrm{E}-02$ \\
\hline Fn1 & $9.0 \mathrm{E}-03 \pm 2.5 \mathrm{E}-03$ & $4.3 \mathrm{E}-02 \pm 2.7 \mathrm{E}-02$ & $1.6 \mathrm{E}-01 \pm 6.9 \mathrm{E}-02$ \\
\hline Mmp2 & $3.5 \mathrm{E}-03 \pm 1.2 \mathrm{E}-03$ & $1.2 \mathrm{E}-02 \pm 7.9 \mathrm{E}-03$ & $1.8 \mathrm{E}-02 \pm 7.5 \mathrm{E}-03$ \\
\hline Mmp14 & $1.9 \mathrm{E}-03 \pm 4.6 \mathrm{E}-04$ & $6.8 \mathrm{E}-03 \pm 3.2 \mathrm{E}-03$ & $1.5 \mathrm{E}-02 \pm 6.8 \mathrm{E}-03$ \\
\hline Ncam1 & $6.2 \mathrm{E}-04 \pm 1.3 \mathrm{E}-04$ & $1.8 \mathrm{E}-03 \pm 1.3 \mathrm{E}-03$ & $4.1 \mathrm{E}-03 \pm 1.7 \mathrm{E}-03$ \\
\hline Postn & $5.3 \mathrm{E}-03 \pm 1.6 \mathrm{E}-03$ & $1.5 \mathrm{E}-01 \pm 9.2 \mathrm{E}-02$ & $2.9 \mathrm{E}-01 \pm 1.2 \mathrm{E}-01$ \\
\hline Sparc & $1.3 \mathrm{E}-02 \pm 3.7 \mathrm{E}-03$ & $7.0 \mathrm{E}-02 \pm 3.7 \mathrm{E}-02$ & $1.1 \mathrm{E}-01 \pm 4.5 \mathrm{E}-02$ \\
\hline Spp1 & $1.3 \mathrm{E}-05 \pm 5.7 \mathrm{E}-06$ & $3.1 \mathrm{E}-04 \pm 4.5 \mathrm{E}-04$ & $2.6 \mathrm{E}-03 \pm 2.2 \mathrm{E}-03$ \\
\hline Tgfbi & $2.0 \mathrm{E}-03 \pm 3.3 \mathrm{E}-04$ & $3.3 \mathrm{E}-03 \pm 1.2 \mathrm{E}-03$ & $7.1 \mathrm{E}-03 \pm 3.6 \mathrm{E}-03$ \\
\hline Thbs1 & $7.2 \mathrm{E}-03 \pm 6.7 \mathrm{E}-03$ & $1.2 \mathrm{E}-02 \pm 7.6 \mathrm{E}-03$ & $4.0 \mathrm{E}-02 \pm 1.6 \mathrm{E}-02$ \\
\hline Thbs2 & $9.0 \mathrm{E}-03 \pm 2.3 \mathrm{E}-03$ & $1.1 \mathrm{E}-02 \pm 3.6 \mathrm{E}-03$ & $3.9 \mathrm{E}-02 \pm 1.4 \mathrm{E}-02$ \\
\hline Timp1 & $2.0 \mathrm{E}-04 \pm 9.4 \mathrm{E}-05$ & $4.1 \mathrm{E}-03 \pm 3.1 \mathrm{E}-03$ & $6.1 \mathrm{E}-03 \pm 3.3 \mathrm{E}-03$ \\
\hline Conto is &
\end{tabular}

Control is unoperated mice; MI is $7 \mathrm{~d}$ post-MI mice.

in ECM remodeling. There were several proteins that influence macrophage activation and function, including macrophage inflammatory protein-1 and osteopontin that increased in post-MI plasma. Via analysis of the plasma changes post-MI [4,7-12], we further confirmed key factors involved in macrophage and fibroblast functions, namely collagen I, MMP-9, and TIMP-1.

In addition, we examined the ECM productions in isolated cardiac fibroblasts stimulated with TGF- $\beta_{1}$. Fibroblast ECM array analysis showed that TGF- $\beta_{1}$ stimulation of cardiac fibroblasts up regulated 5 genes and down regulated 7 genes, which are shown in Table 3. Collagen I expression and SPARC expression levels were doubled, and TIMP-1 expression increased 5-fold in response to TGF- $\beta_{1}$ stimulation at the concentration of $10 \mathrm{ng} / \mathrm{mL}$. These experimental data indicated a primary regulatory effect of TGF- $\beta_{1}$ on fibroblast ECM production. Interestingly, the 5 up regulated genes are among the 17 ECM genes that were significantly expressed in the LV, indicating that the cardiac fibroblast is likely the major tissue source for these ECM genes (Table 1).

We also examined the correlations between LV wall thickness with 6 genes that were over expressed postMI. The $R^{2}$ values were 0.76 for collagen $1 \alpha 1,0.64$ for collagen $2 \alpha 1,0.75$ for collagen $5 \alpha 1,0.60$ for periostin, 0.61 for osteopontin, and 0.63 for TGF- $\beta_{1}$.

In summary, the key factors identified were macrophages, fibroblasts, TGF- $\beta_{1}$, MMP-9, and collagen. Based on these experimental results, we developed a 
Table 2 Multi-analyte Profiling of Control and 7 day Post-MI Plasma

\begin{tabular}{lccc}
\hline & Control $\mathbf{n}=\mathbf{6}$ & $\mathbf{7} \mathbf{d}$ Ml $\mathbf{n}=\mathbf{7}$ & $\mathbf{P}$ value \\
\hline Clusterin $(\mu \mathrm{g} / \mathrm{mL})$ & $330 \pm 40$ & $510 \pm 200$ & 0.046 \\
\hline Cystatin-C $(\mathrm{ng} / \mathrm{mL})$ & $360 \pm 20$ & $530 \pm 100$ & 0.008 \\
\hline Eotaxin $(\mathrm{pg} / \mathrm{mL})$ & $1500 \pm 200$ & $1900 \pm 400$ & 0.049 \\
\hline Fibrinogen $(\mathrm{mg} / \mathrm{mL})$ & $12 \pm 2$ & $19 \pm 5$ & 0.012 \\
\hline Haptoglobin $(\mathrm{\mu g} / \mathrm{mL})$ & $83 \pm 30$ & $180 \pm 50$ & 0.002 \\
\hline Macrophage $\mathrm{Inflammatory} \mathrm{Protein-1} \mathrm{gamma}(\mathrm{ng} / \mathrm{mL})$ & $24 \pm 4$ & $33 \pm 9$ & 0.042 \\
\hline Matrix Metalloproteinase-9 $(\mathrm{ng} / \mathrm{mL})$ & $71 \pm 9$ & $96 \pm 20$ & 0.009 \\
\hline Myeloperoxidase $(\mathrm{ng} /(\mathrm{mL})$ & $58 \pm 10$ & $100 \pm 30$ & 0.006 \\
\hline Osteopontin $(\mathrm{ng} / \mathrm{mL})$ & $250 \pm 60$ & $390 \pm 100$ & \\
\hline Serum Amyloid Protein $(\mu \mathrm{g} / \mathrm{mL})$ & $21 \pm 3$ & $33 \pm 9$ & 0.041 \\
\hline TIMP-1 $(\mathrm{ng} / \mathrm{mL})$ & $0.8 \pm 0.1$ & $3.7 \pm 2.0$ & 0.013 \\
\hline
\end{tabular}

framework of the interaction loops among the identified key factors (Figure 1).

\section{Linking Experimental Results to Mathematical Modeling Framework}

In the ECM construction pathway, collagen is secreted by fibroblasts. Growth and secretion of fibroblasts are stimulated by TGF- $\beta_{1}$ (Table 3 ). In ECM destruction pathway, MMP-9 is a key factor by cleaving collagen. The major source of MMP-9 is the macrophage, which infiltrates into the infarct region post-MI. The majority of macrophages in the LV post-MI are differentiated from peripheral blood monocytes stimulated by chemoattractants including TGF- $\beta_{1}$ [17]. The major source of TGF $-\beta_{1}$ is the macrophage. Meanwhile, there are

Table 3 Fibroblast ECM array in serum free control and $10 \mathrm{ng} / \mathrm{ml}$ TGF- $\beta$ stimulated fibroblasts

\begin{tabular}{|c|c|c|c|}
\hline & Serum Free & TGF- $\beta$ & $p$ Value \\
\hline \multicolumn{4}{|c|}{ ECM/Growth Factors } \\
\hline Col1a1 & $4.842 \pm 1.399$ & $9.614 \pm 3.324$ & 0.028 \\
\hline Col5a1 & $0.301 \pm 0.085$ & $0.605 \pm 0.230$ & 0.038 \\
\hline Fbln1 & $0.012 \pm 0.005$ & $0.008 \pm 0.004$ & 0.032 \\
\hline Sparc & $2.709 \pm 0.204$ & $4.932 \pm 0.379$ & $<0.001$ \\
\hline Tgfbi & $0.022 \pm 0.016$ & $0.013 \pm 0.015$ & 0.009 \\
\hline \multicolumn{4}{|c|}{ Cell Adhesion Molecules } \\
\hline Ncam1 & $0.043 \pm 0.016$ & $0.169 \pm 0.054$ & 0.011 \\
\hline Pecam1 & $0.000060 \pm 0.000012$ & $0.000022 \pm 0.000011$ & 0.015 \\
\hline Sgce & $0.187 \pm 0.035$ & $0.146 \pm 0.018$ & 0.030 \\
\hline Vcam1 & $0.301 \pm 0.136$ & $0.161 \pm 0.088$ & 0.031 \\
\hline \multicolumn{4}{|c|}{ MMPs/TIMPs } \\
\hline Mmp7 & $0.0000075 \pm 0.0000011$ & $0.0000056 \pm 0.0000004$ & 0.026 \\
\hline Timp1 & $0.052 \pm 0.022$ & $0.272 \pm 0.136$ & 0.035 \\
\hline Timp2 & $0.326 \pm 0.109$ & $0.188 \pm 0.050$ & 0.027 \\
\hline
\end{tabular}

interactions between the ECM construction and destruction pathways: a) MMP-9 regulates ECM construction by activating TGF- $\beta_{1}$ which stimulates collagen synthesis; b) TGF- $\beta_{1}$ induces TIMP-1, which inhibits collagen degradation by blocking MMP-9 activity. Linking these key factors with their sources and effects allows us to develop the mathematical model for quantitative analysis.

\section{Mathematical Modeling}

We established a set of nonlinear differential equations to model the temporal interactions among the key factors identified by our experimental results. The model incorporated the following variables: macrophage cell density $\left(\mathrm{M}_{\Phi}\right.$, cells $\left./ \mathrm{mm}^{3}\right)$, fibroblast cell density ( $\mathrm{F}$, cells/ $\left.\mathrm{mm}^{3}\right)$, collagen concentration $(\mathrm{C}, \mu \mathrm{g} / \mu \mathrm{L})$, TGF- $\beta_{1}$ concentration $\left(\mathrm{T}_{\beta}, \mathrm{pg} / \mu \mathrm{L}\right)$, and activated MMP-9 concentration $\left(\mathrm{M}_{9 \mathrm{~A}}, \mathrm{pg} / \mu \mathrm{L}\right)$. Rates of cell number change were determined by the summation of constructive effects (migration rate or proliferation rate) and destructive effects (death rate or removal rate). Rates of chemical factors (TGF- $\beta_{1}$, MMP-9, collagen, etc) change were determined by the net difference between the synthesis rate and degradation rate.

Four assumptions were used based on experimental results: 1) All monocytes that migrate to the infarct region are differentiated to macrophages [18]; all activated macrophages are differentiated from peripheral blood monocytes since previous studies have shown that $<5 \%$ of macrophages undergo mitotic division [19]; 2) The major source of fibroblasts is the resident cell and the contribution of circulating fibroblasts is ignored [20]; 3) The majority (80\%) of TGF- $\beta_{1}$ secreted at the injured site becomes activated [21,22]; 4) ECM proteins in the infarct region are secreted by local cells. Our experimental data showed that ECM gene expression was higher in the infarct region than the expression in the remote region, and ECM gene levels in the remote 


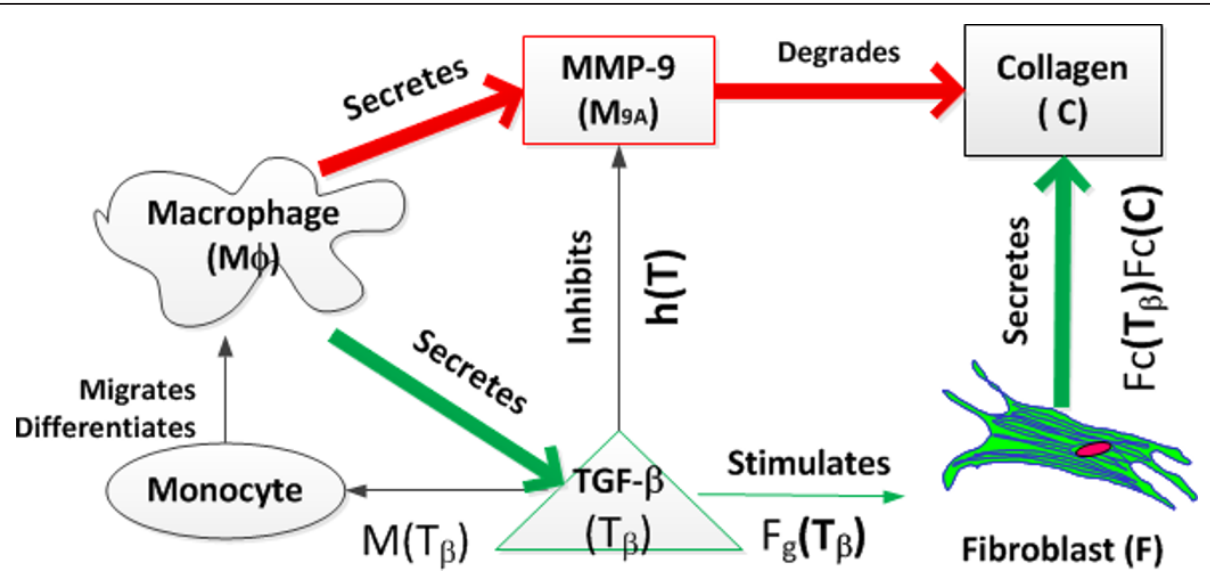

Figure 1 A working model of post-MI scar formation and remodeling with constructive and destructive modules. Red arrows represent the destruction pathway and green arrows represent the construction pathway. The regulation scheme includes lines in black, which can be a driving or a triggering stimulus. LV remodeling outcomes are denoted as collagen concentrations in the scar tissue.

region were higher than that in the LV of controls, indicating a local source of ECM production.

Accordingly, the scar formation post-MI was modeled by the following set of differential equations

$$
\begin{aligned}
& M_{\phi}^{\prime}=\overbrace{M\left(T_{\beta}\right)}^{\text {inf iltration }}-\overbrace{d_{M \Phi} M \Phi}^{\text {removal }}, \\
& k_{\text {crowding }}=k_{\text {mem }}(t)+M_{\Phi} / \rho_{M_{\Phi}}+F / \rho_{F}+C / \rho_{C} \text {, } \\
& F^{\prime}=\overbrace{k_{F} F_{g}\left(T_{\beta}\right) F\left[1-k_{\text {crowding }}\right]}^{\text {fibroblast proliferation rate with crowding effect }}-\overbrace{d_{F} F}^{\text {apoptosis }}, \\
& T_{\beta}^{\prime}=\overbrace{k_{M \Phi T} M_{\Phi}}^{M_{\Phi} \text { secretion }}+\overbrace{k_{F T} F}^{\begin{array}{c}
\text { fibroblast } \\
\text { secretion }
\end{array}}+\overbrace{u_{T}}^{\text {TGF } \beta} \begin{array}{c}
\text { activation } \\
\text { degradation }
\end{array}-\overbrace{d_{T_{\beta}} T_{\beta}}^{\text {ind }}, \\
& \mathrm{M}_{9 \mathrm{~A}}+\mathrm{C} \underset{\mathrm{k}_{\text {off }}}{\stackrel{\mathrm{k}_{\text {on }}}{\longrightarrow}}\left[\mathrm{CM}_{9}\right] \stackrel{\mathrm{k}_{\text {onc }}}{\longrightarrow} \mathrm{CID}+\mathrm{MMP} 9 \\
& M_{9 A}^{\prime}=\overbrace{k_{M_{\Phi} M_{9}} M_{\Phi}}^{\text {secretion by } M_{\Phi} \text { activation by }} \overbrace{h(T)}^{T G F-\beta}+\overbrace{k_{0 f f}\left[C M_{9}\right]-k_{o n} M_{9 A} C}^{\text {ocupied for collagen degradation }}-\overbrace{d_{M_{9}} M_{9 A}}^{\text {inactivation }}
\end{aligned}
$$

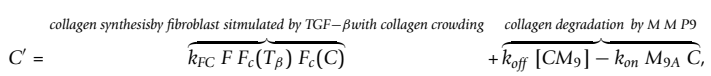

$$
\begin{aligned}
& {\left[\mathrm{CM}_{9}\right]^{\prime}=k_{o n} \mathrm{M9}_{A} \cdot \mathrm{C}-k_{\text {onc }}\left[\mathrm{CM}_{9}\right] .}
\end{aligned}
$$

The parameters used in these equations with their biological meanings, experimental values, units, and references were listed in Table 4. The interaction functions $\mathrm{M}\left(\mathrm{T}_{\beta}\right), F_{g}\left(T_{\beta}\right)$, and $\mathrm{Fc}\left(\mathrm{T}_{\beta}\right)$, were established based on in vivo, and in vitro experiments [17,23-26]. We employed the function $\mathrm{Fc}(\mathrm{C})$ in a form given by Waugh and colleagues $[27,28]$. The forms of these functions we took in this study were described in equation 8.

$$
\begin{aligned}
M\left(T_{\beta}\right) & =0.3350 T_{\beta}^{3}-6.3095 T_{\beta}^{2}+32.2810 T_{\beta}+57.3019 \\
F_{g}\left(T_{\beta}\right) & =0.0492 T_{\beta}^{3}-0.9868 T_{\beta}^{2}+6.5408 T_{\beta}+7.1092 \\
F_{c}\left(T_{\beta}\right) & =0.0092 T_{\beta}^{3}-0.1552 T_{\beta}^{2}+0.6279 T_{\beta}+0.2527 \\
F_{c}(C) & =-4.33 \times 10^{-10} \mathrm{C}^{2}+0.0000009 \mathrm{C}^{2}-0.00055 \mathrm{C}+0.13
\end{aligned}
$$

Plot of these constructed functions and the available experimental data were shown in Figure 2.

Equation 1 determines the rate of macrophage $\left(\mathrm{M}_{\Phi}\right)$ infiltration. The function $M\left(T_{\beta}\right)$ describes the migration rate of macrophages to the scar tissue [17]. Since we assumed that all monocytes differentiated into macrophages (assumption 1), $\mathrm{M}\left(\mathrm{T}_{\beta}\right)$ also represents the migration of monocytes stimulated by TGF- $\beta_{1}$. Parameter $\mathrm{d}_{\mathrm{M} \Phi}$ denotes the emigration rate of macrophages [29], since macrophages do not die locally in the scar tissue but emigrate to the lymph node system for disposal.

Equation 2 determines the crowding effect of myocytes, endothelial cells, vascular smooth muscles cells, fibroblasts, macrophages, and collagen in the myocardium, which are affected by total environment density $[30,31]$. Parameter $k_{\text {mem }}(t)=0.17+0.56 e^{-d_{m c} t}$ denotes the crowding effects contributed by myocytes, endothelial cells, and vascular smooth muscle cells. The parameter 0.17 represents the total percentage of endothelial and smooth muscle cells that account for $7 \%$ and $10 \%$ of total cell numbers in normal mouse myocardium, respectively [32]. Parameter 0.56 represents the percentage of myocytes $(56 \%)$ in normal mouse myocardium [32]. Parameter $d_{m c}=0.05$ represents the rate of myocyte cell death since ischemic myocytes undergo necrosis in the infarct region post-MI. The crowding effect of macrophages, fibroblasts, and collagen was considered by calculating the normalized density with respect to their maximum density in scar tissue [28]. Temporal 
Table 4 Pre-determined parameters in the mathematical model

\begin{tabular}{|c|c|c|c|c|}
\hline Symbol & Biological meaning & Value & Units & Ref \\
\hline$\overline{d_{M \Phi}}$ & Macrophage removal rate ${ }^{* *}($ eqn 1$)$ & 0.6 & day $^{-1}$ & {$[29]$} \\
\hline$\rho_{\mathrm{M \Phi}}$ & maximal macrophage density (eqn 2) & 2500 & cells $/ \mathrm{mm}^{3}$ & {$[28]$} \\
\hline$\overline{\rho_{\mathrm{F}}}$ & maximal fibroblast density(eqn 2) & 1250 & cells $/ \mathrm{mm}^{3}$ & {$[28]$} \\
\hline$\overline{\rho_{C}}$ & maximal collagen density (eqn 2) & 3300 & $\mu \mathrm{g} / \mathrm{mm}^{3}$ & {$[28]$} \\
\hline $\mathrm{k}_{\mathrm{F}}$ & Fibroblast growth rate* (eqn 3) & 0.924 & day $^{-1}$ & {$[62]$} \\
\hline $\mathrm{d}_{\mathrm{F}}$ & Fibroblast apoptosis rate (eqn 3) & 0.12 & day $^{-1}$ & [33] \\
\hline $\mathrm{k}_{\mathrm{M \Phi} T}$ & Macrophage TGF- $\beta$ production rate (eqn 4) & 0.07 & $\mathrm{pg} / \mathrm{cell} / \mathrm{day}$ & [34] \\
\hline $\mathrm{k}_{\mathrm{FT}}$ & Fibroblast TGF- $\beta$ production rate (eqn 4) & 0.004 & $\mathrm{pg} / \mathrm{cell} / \mathrm{day}$ & [35] \\
\hline $\mathrm{d}_{\mathrm{T} \beta}$ & TGF- $\beta$ degradation rate (eqn 4$)^{*}$ & 15 & day $^{-1}$ & [36] \\
\hline $\mathrm{K}_{\mathrm{M} \phi \mathrm{M} 9}$ & Macrophage secretion MMP9 rate (eqn 5) & 3 & pg/cell/day & estimated \\
\hline $\mathrm{d}_{\mathrm{M} 9}$ & MMP-9 degradation rate(eqn 5) & 0.875 & day $^{-1}$ & {$[63-65]$} \\
\hline$\overline{\mathrm{k}_{\mathrm{on}}}$ & Kinetic reaction speed (eqn 5) & $3 \times 10^{-4}$ & $1 /\left(\mu \mathrm{g} / \mathrm{mm}^{3}\right) \mathrm{s}^{-1}$ & {$[42,66,67]$} \\
\hline $\mathrm{k}_{\text {off }}$ & Kinetic reaction speed (eqn 5) & $4 \times 10^{-4}$ & $\mathrm{~s}^{-1}$ & {$[42,66,67]$} \\
\hline konc & Kinetic reaction speed (eqn 6) & 0.004 & $s^{-1}$ & {$[42,66,67]$} \\
\hline $\mathrm{k}_{\mathrm{FC}}$ & Fibroblast collagen production rate (eqn 6) & 20 & $\mu \mathrm{g} /$ cell/day & [41] \\
\hline
\end{tabular}

*The growth rate of cells was determined by the population doubling time $\left(T_{2}\right)$ via equation $k=\ln 2 / T_{2}$ [68].

** Since macrophages emigrate from the scar tissue to lymph node system instead of dying locally in the scar tissue, the removal rate of macrophage, $d_{M A}$, was used in our model.

$¥$ The decaying rate of chemical factors was calculated from their half-life $\left(T_{1 / 2}\right)$ via the equation $d=\ln 2 / T_{1 / 2}[68]$.

profiles of total crowding effects, crowding effects contributed by macrophages, fibroblasts, and collagen, and the parameter $k_{\text {mem }}(t)$ were shown in Figure 3.

Equation 3 determines the rate of fibroblast (F) density changes based on the assumption that majority of fibroblasts come from the proliferation of resident cells (assumption 2). The function $F_{\mathrm{g}}\left(T_{\beta}\right)$ denotes the stimulating effects of TGF- $\beta_{1}$ on the growth rate of fibroblasts [17]. Parameter $d_{F}$ represents the apoptosis rate of the fibroblast [33].

Equation 4 determines the rate of TGF- $\beta_{1}$ concentration change, wherein $\mathrm{k}_{\mathrm{FT}}$ denotes the TGF- $\beta_{1}$ secretion rate of fibroblasts [34] and $\mathrm{k}_{\mathrm{M} \Phi \mathrm{T}}$ denotes the TGF- $\beta_{1}$ secretion rate of macrophages [35] since a major source of TGF- $\beta_{1}$ in the scar tissue is the activated macrophage. Parameter $d_{T \beta}$ represents the degradation rate of TGF- $\beta_{1}$, which can be calculated from the half life data [36].

TGF- $\beta_{1}$ gene levels demonstrated temporal progression at the early stage post-MI. Gene expression profile of TGF- $\beta_{1}$ increased post-MI, peaked at day 2 , and returned to normal levels after day 7 in mice post-MI [37]. Since majority of TGF- $\beta_{1}$ secreted in the infarct is activated (Assumption 3), gene expression profile can be used as an activation pattern of TGF- $\beta_{1}$. The function, $u t$ denotes temporal profile of TGF- $\beta_{1}$ activation postMI [38-40] and works as the input in the simulation. It's worth to mention that TGF- $\beta 1$ activation levels were different with respect to different scar size. A temporal profile of $u t$ representing small scar was shown in Figure 3.

Equation 5 determines the rate of activated MMP-9 concentration change. Proteolytic collagen degradation with activated MMP-9 is described in equation $5 \mathrm{a}$, where $\mathrm{M}_{9 \mathrm{~A}}, \mathrm{C}, \mathrm{CM}_{9}$, and CID denote activated MMP-9, collagen, binding of MMP-9 and collagen, and degraded collagen peptide concentration, respectively. MMP-9 is inhibited primarily by TIMP-1, and TIMP- 1 is induced by TGF- $\beta_{1}$. Thus, we established an inhibition function $\mathrm{h}(\mathrm{T})=1 /\left(1+\mathrm{T}_{\beta} / \mathrm{T}_{\beta \mathrm{N}}\right)$ with $\mathrm{T}_{\beta \mathrm{N}}=6.0 \mathrm{pg} / \mu \mathrm{L}$ to represent the inhibition effect.

Equation 6 determines the rate of collagen concentration changes. Collagen secretion rate by fibroblasts was denoted by parameter $K_{F C}$. Meanwhile, the function, $F_{c}$ $\left(T_{\beta}\right)$, characterizes effects of TGF- $\beta_{1}$ on collagen secretion rate by fibroblasts $[23,41]$. Function, $F_{c}(c)$, denotes the effect of collagen density on fibroblast secretion rate $[27,28]$.

Equation 7 determines the concentration change of $\mathrm{CM}_{9}$, based on the theoretical model for collagen degradation by MMPs proposed by Popel's group [42,43].

\section{Computational simulations}

Computational simulations of scar formation (collagen deposition) were carried out by solving the nonlinear differential equations with MATLAB. Initial conditions of the fibroblast and macrophage densities were chosen as $F(0)=20$ cells $/ \mathrm{mm}^{3}$ and $M_{\Phi}(0)=5$ cells $/ \mathrm{mm}^{3}$. 

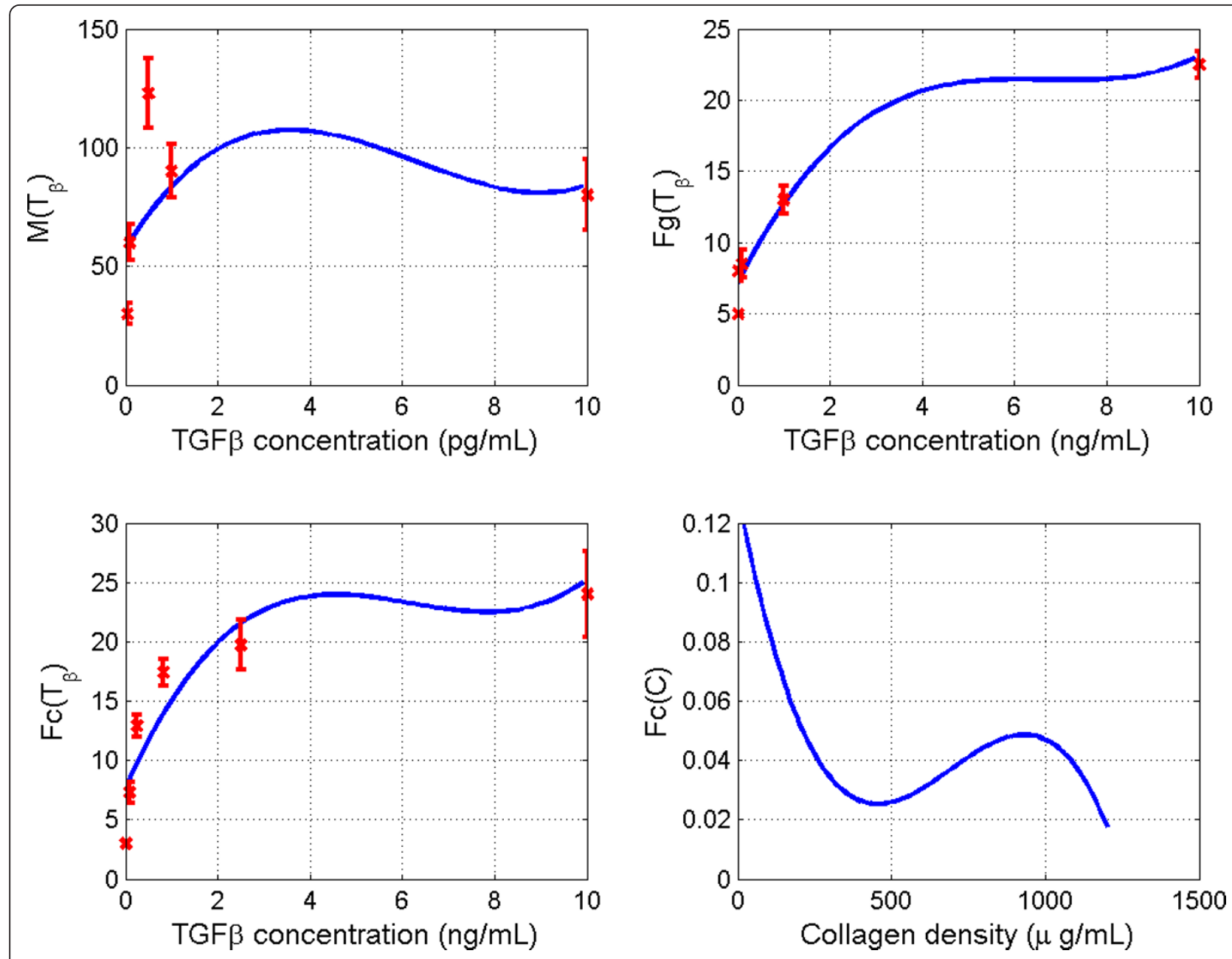

Figure 2 Macrophage migration rate $M\left(T_{\beta}\right)[17]$, fibroblast growth rate $\mathrm{Fg}\left(\mathrm{T}_{\beta}\right)[17]$, and fibroblast secretion rate $\mathrm{Fc}\left(\mathrm{T}_{\beta}\right)[23,41]$ plotted as functions of TGF- $\beta_{1}$ concentration. The original experimental data ( $x$, Mean \pm SD) are shown for comparison. The function $\mathrm{Fc}(\mathrm{C})$ was provided by Waugh et al $[27,28]$.

Accordingly, $\mathrm{T}_{\beta}(0)=0.21 \mathrm{pg} / \mu \mathrm{L}, \mathrm{M}_{9 \mathrm{~A}}(0)=7.1 \mathrm{pg} / \mu \mathrm{L}, \mathrm{C}$ $(0)=839.5 \mu \mathrm{g} / \mu \mathrm{L}, \mathrm{CM}_{9}(0)=447.6 \mu \mathrm{g} / \mu \mathrm{L}$ were calculated by the equilibriums of equations 1-7 for normal LV. All the simulations shown in this study used the same initial conditions. The initial conditions were chosen based on measurements in the normal LV for both the control and MI groups (MI induced at day 0 ). The simulations covered the LV remodeling process from day 0 to day 30 post-MI.

\section{Model validation}

To validate our mathematical model, we compared our simulation results to experimental data from our lab or reported in the literature $[9,12,44]$. We normalized macrophage and fibroblast cell densities and MMP-9 concentrations to the corresponding measurements in the normal LV and plot the experimental data (Mean \pm
SD) in Figure 4. Our computational simulation results were also normalized to the corresponding initial conditions. This normalization will give us the relative fold changes of macrophage and fibroblast cell densities and MMP-9 concentration. The simulation results showed similar progression trend of cell densities and MMP-9 concentration profiles, peak values, and stable values as the experimental results (Figure 4).

In addition, our simulations correctly predicted MMP9 responses to three TGF- $\beta_{1}$ stimuli corresponding to reduced, normal, and elevated post-MI activation strength. Others have reported an early increase of MMP-9 levels of $78 \pm 19 \mathrm{pg} / \mu \mathrm{L}$ for small infarcts and $195 \pm 63 \mathrm{pg} / \mu \mathrm{L}$ for large infarcts $[45,46]$. These experimental results agreed with the MMP-9 predictions by our mathematical model, which peak at $80 \mathrm{pg} / \mu \mathrm{L}$ for small infarcts, and $220 \mathrm{pg} / \mu \mathrm{L}$ for large infarcts, 

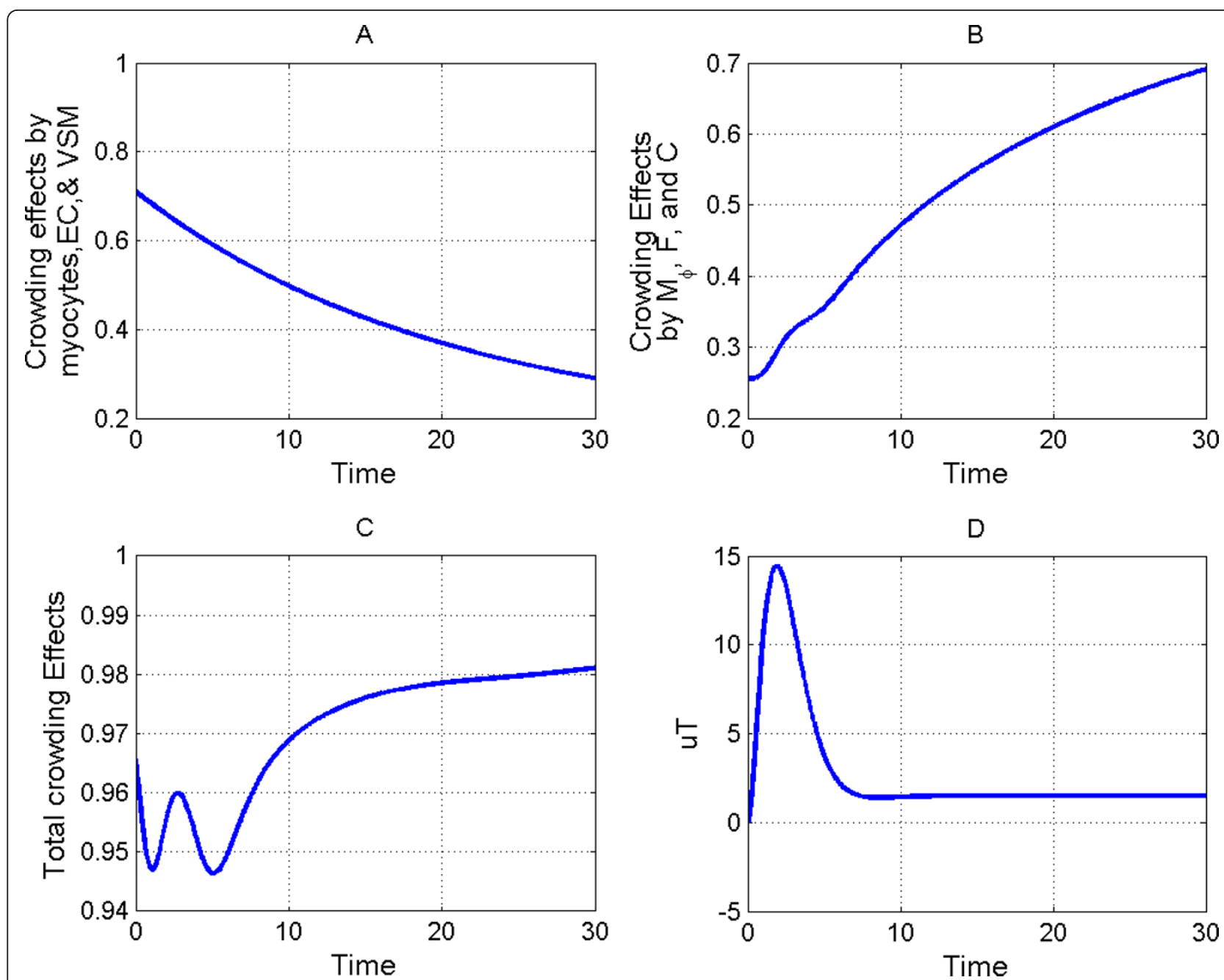

Figure 3 Plots of crowding effects (equation 2 ) and TGF- $\beta_{1}$ activation function $u_{T}$ (equation 4). A: Crowding effects $\left(k_{m e m}(t)\right.$ in equation 2) contributed by myocytes, endothelial cells, and vascular smooth muscle cells. B: Crowding effects contributed by macrophages, fibroblasts, and collagen in the scar tissue. C: Total crowding effects imposed by the environment. D: TGF- $\beta_{1}$ activation function, $u_{T}$ according to small scar size. Activation peak time is at day 2 post-Ml with amplitude at $15 \mathrm{pg} / \mu \mathrm{L} /$ day.

respectively. MMP-9 profiles were shown in Figure 5 and details of the simulation setup for Figure 5 were explained as follows.

\section{Effects of TGF- $\beta_{1}$ levels}

We employed activation of TGF- $\beta_{1}, u_{T}$ in equation 4 , at reduced, normal, and elevated post-MI strength. The activation function peaked at 15,30 , and $60 \mathrm{pg} / \mu \mathrm{L} /$ day, according to active expression levels observed in small, median, and very large infarcts, respectively. Temporal profiles of cell densities of macrophages, fibroblasts, concentrations of MMP-9, collagen, and TGF- $\beta_{1}$ responses to the stimuli $u_{T}$ are shown in Figure 5. For the TGF- $\beta_{1}$ stimulus level setting at $30 \mathrm{pg} / \mu \mathrm{L} /$ day (a normal post-MI level in mice), TGF- $\beta_{1}$ peaked after day 2 post-MI, macrophage density peaked at day 3, MMP-9 concentration peaked at day 4 , and all were returned to normal levels at 30 days post-MI. In contrast, fibroblast density and collagen density continued to increase beginning at day 4 , reached a stable value after day 20 post-MI, and then remained at a higher equilibrium level at day 30 post-MI (blue solid line in Figure 5). This computational predictions agreed with the experimental observations on the peak time of macrophages $[9,12]$, and progression trend of MMP-9 [10] and collagen for stable LV remodeling [47].

In the case of reduced TGF- $\beta_{1}$ levels (with an activation peak at $15 \mathrm{pg} / \mu \mathrm{L} /$ day in Figure 3), less monocytes were attracted to the infarct. Thereby, less macrophages and MMP-9 appeared at the early stage. The reduced MMP-9 levels slowed down collagen degradation, leading to a higher collagen concentration (black dotted lines in Figure 5. This simulation agreed with the 

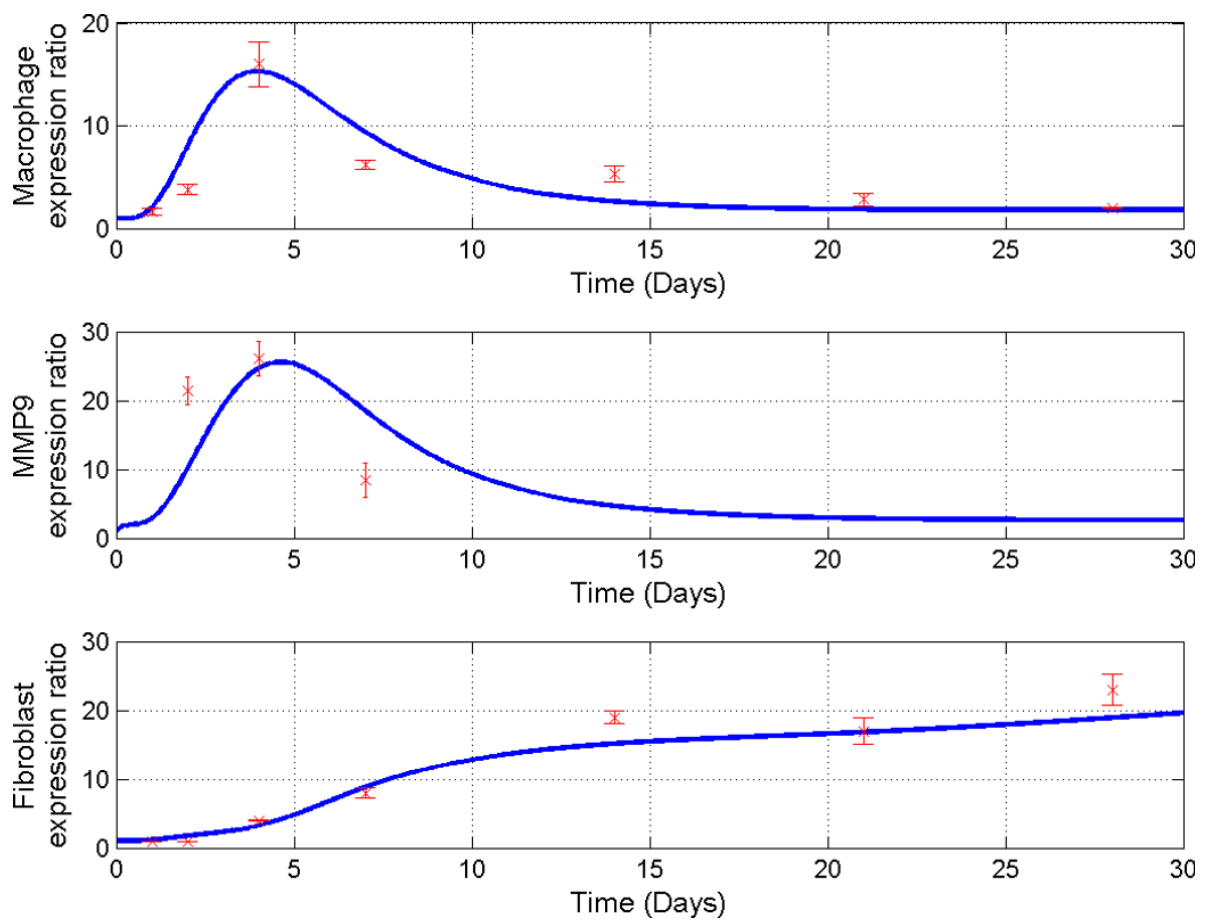

Figure 4 The relative ratio changes of fibroblast density, macrophage density, and MMP-9 concentrations. Computational results were normalized to initial conditions and are shown in solid lines. Previously published experimental results were normalized to the corresponding measurements in control group and are shown as $\times($ Mean \pm SD). All experiments were carried out in mice with Ml induced by coronary artery ligation. The fibroblast and macrophage densities were collected from C57BL/6J mice [12]. MMP-9 profile was collected from 129SV mice [45,46].
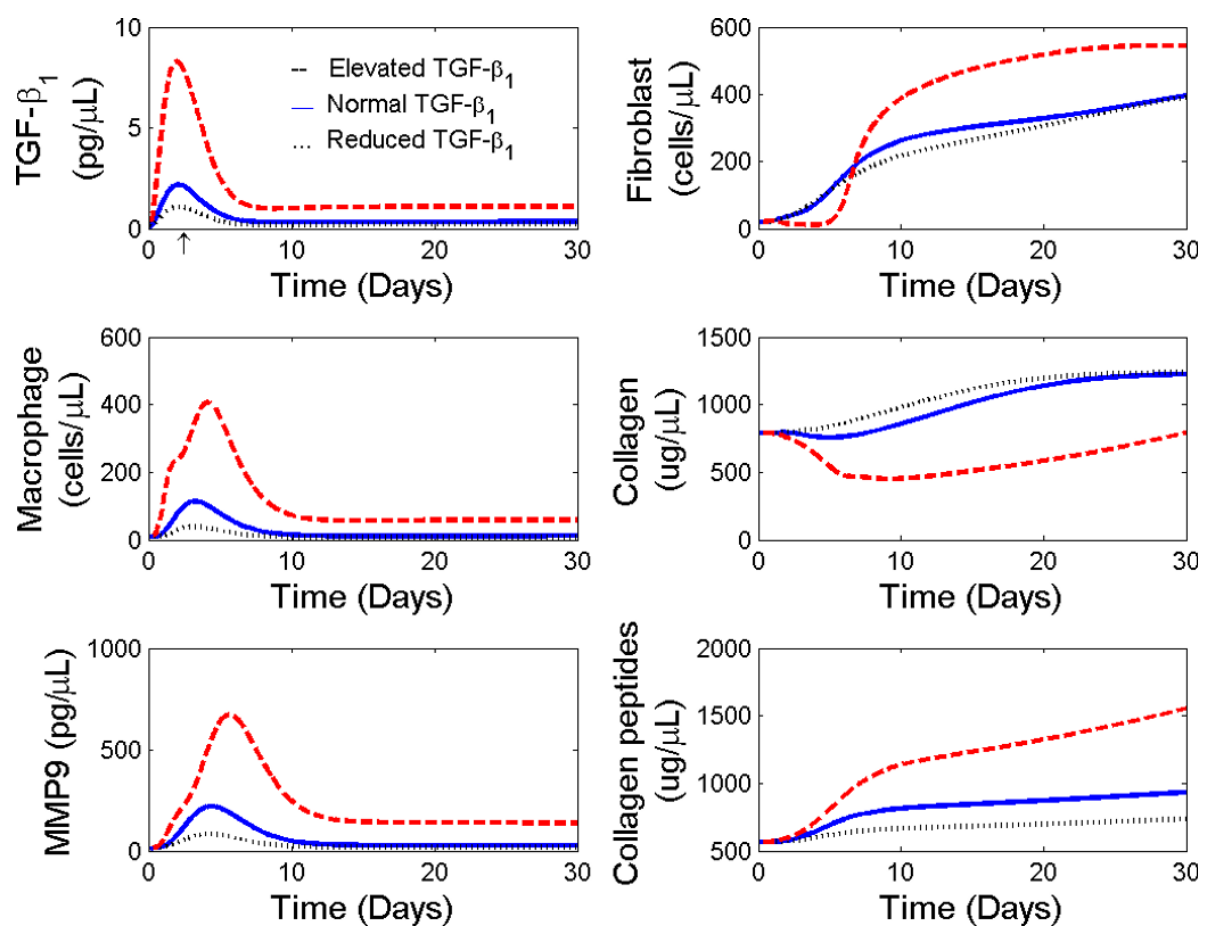

Figure 5 Temporal profiles of TGF- $\beta_{1}$, macrophages, MMP-9, fibroblasts, collagen, and collagen peptides from days 0 to 30 post-MI in response to low (...), median (blue line), and elevated (red dash) TGF- $\beta_{1}$ stimuli. The initial conditions were set to $F(0)=20$ cells $/ \mathrm{mm}^{3}$ and $M_{\Phi}(0)=5$ cells $/ \mathrm{mm}^{3}, T_{\beta}(0)=0.21 \mathrm{pg} / \mu \mathrm{L}, \mathrm{M}_{9 A}(0)=7.1 \mathrm{pg} / \mu \mathrm{L}, \mathrm{C}(0)=839.5 \mu \mathrm{g} / \mu \mathrm{L}, \mathrm{CM}_{9}(0)=447.6 \mu \mathrm{g} / \mu \mathrm{L}$, according to measurements in normal myocardium. The symbol $\uparrow$ indicates the peak time of TGF- $\beta_{1}$ stimulus. 
temporal profiles of macrophage and fibroblast density $[9,12]$, and relative low expression levels of MMP-9 for moderate size of infarcts compared to large infarcts $[46,48]$.

When the TGF- $\beta_{1}$ stimulus strength was elevated to a level 2 -fold higher than normally seen post-MI in mice, more macrophages infiltrated to the infracted region in the early days (Figure 5 red dash lines). Elevated macrophage infiltration led to high levels of crowding effect and high concentrations of MMP-9 for collagen degradation. Therefore, fibroblast growth was inhibited earlier due to the crowding effect, which led to less collagen secretion and a net negative collagen deposition. These results indicated an increased early susceptibility to LV rupture between day 2 to 6 post-MI and prolonged LV remodeling for those mice that did not rupture. Though we know that LV ruptures frequently occurred at day 24 post-MI in a normal remodeling process [49], this simulation has not been examined experimentally and raises some interesting hypotheses.

\section{Effects of MMP-9 interventions on ECM destruction}

With the validated parameter settings, we also used the mathematical model to predict the effects of MMP-9 interventions at different strengths and intervention times. Specifically, we simulated the LV remodeling responses to three different MMP-9 interventions postMI: 1) elevation of MMP-9 level (200 pg/ $\mathrm{LL})$ beginning at 8 hours post-MI to mimic the earlier increase of MMP-9 levels seen with reperfusion, 2) elevation of MMP-9 levels $(200 \mathrm{pg} / \mu \mathrm{L})$ beginning at 7 days post-MI to mimic a prolonged macrophage infiltration, and 3) reduced elevation of MMP-9 levels $(100 \mathrm{pg} / \mu \mathrm{L})$ beginning at 7 day to mimic therapeutic targeting of MMP-9. The LV remodeling responses were shown in Figure 6. Early MMP-9 intervention (scenario 1) significantly decreased collagen density at day 30 post-MI, consistent with the beneficial effects seen with reperfusion. Elevated MMP-9 levels (scenarios 1, 2, and 3) led to reduced collagen density post-MI, compared to collagen levels seen in LV remodeling outcomes without MMP-9 intervention, when MMP-9 levels would be starting to fall by day 7. Compared to scenario 2, reducing MMP-9 intervention levels at day 7 post-MI (scenario 3) had less effect on collagen degradation, suggesting that the primary effects of MMP-9 might occur before day 7 .

\section{Discussion}

This study is the first investigation to integrate mathematical modeling with ECM and fibroblast gene array data and plasma analytes to predict ECM remodeling post-MI. We have integrated in vivo, in vitro, and in silico approaches to dissect the complicated interactions among multiple regulatory factors in LV remodeling. As such, this study provides a promising modeling approach for elucidating the complicated LV remodeling process. The most important findings of this study are highlighted as follows. 1) The balance between ECM construction and destruction kinetics is likely the key determinant of scar formation, and interventions to either the construction or destruction side lead to different remodeling outcomes. 2) Dynamic interactions among key factors in LV remodeling determine LV remodeling outcomes post-MI. Altering initial conditions, intervention strengths, or intervention times have significant effects on LV remodeling outcomes, and these effects could be simulated accurately by our model. 3) Collagen, MMP-9, TGF- $\beta_{1}$, and TIMP-1 are critical biomarker candidates of $\mathrm{LV}$ remodeling outcomes.

Our experimental results on microarray and plasma data provided the foundations to build our computational framework. We examined 84 ECM genes and chose the 17 genes that were most highly overexpressed in the infarct region compared to both control and non-infarcted groups ( $>2.5$-fold over-expression). The expression levels of several of these factors were further verified by our plasma data at protein level. One interesting finding was that SPP1 (osteopontin) gene expression levels increased 206-fold in the infarct region compared to the control group at day 7 post-MI, suggesting strong macrophage activation. The plasma protein levels of osteopontin increased from $250 \pm 60$ $\mathrm{ng} / \mathrm{mL}$ in controls to $390 \pm 100 \mathrm{ng} / \mathrm{mL}$ in post-MI samples, which adds support for the critical role of macrophages in our mathematical model. Therefore, the primary selection of the most highly changed genes allowed us to focus on the most significant factors at gene level and predict the possible interactions at protein level and cellular level.

An interesting observation was that MMP-9 mRNA levels did not increase in our gene array analysis, but MMP-9 protein levels increased in the plasma data. It is well known that MMP-9 protein levels and activation were increased at day 7 post-MI. This conflicting phenomena is caused by pre-formed MMP-9 proteins stored in leukocytes, which do not rely on increased gene expression to induce MMP-9 secretion and activation [50]. In addition, the shift from a normal ventricle composed of cardiac myocytes, endothelial cells, and smooth muscle cells to an infarcted ventricle comprised primarily of cardiac fibroblasts and inflammatory cells could result in a quantitative no gain in gene expression level but qualitative increase in MMP-9 function due to increased activation and increased substrate availability. Karl Weber's group showed that MMP-9 protein levels increased early post-MI, but the mRNA levels were not elevated [51]. We have also shown that MMP-9 activation increases upon reperfusion in a dog model of 

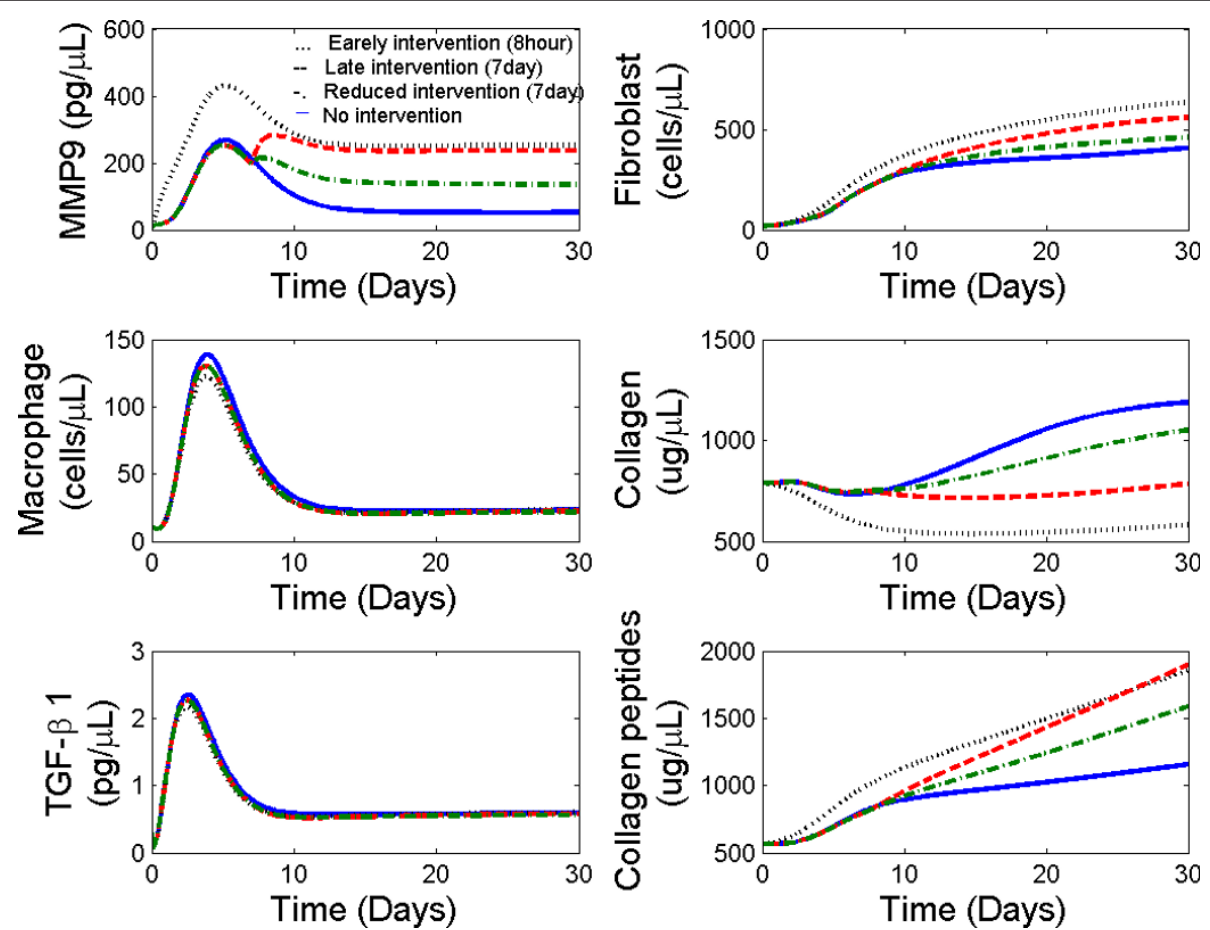

Figure 6 Temporal profiles of MMP-9, macrophages, TGF- $\beta_{1}$, fibroblasts, collagen, and collagen peptides from days 0 to 30 post-MI at different MMP-9 interventions. The profiles include progressive changes in response to MMP-9 intervention at day 1 (...) and day 7 (red dash), as well as reduced MMP-9 intervention strength at day 7 post-MI (green dot-dash), and no intervention (blue line). The initial conditions were set to $F(0)=20$ cells $/ \mathrm{mm}^{3}$ and $M_{\Phi}(0)=5$ cells $/ \mathrm{mm}^{3}, T_{\beta}(0)=0.21 \mathrm{pg} / \mu \mathrm{L}, \mathrm{M}_{9 \mathrm{~A}}(0)=7.1 \mathrm{pg} / \mu \mathrm{L}, \mathrm{C}(0)=839.5 \mu \mathrm{g} / \mu \mathrm{L}, \mathrm{CM}(0)=447.6 \mu \mathrm{g} / \mu \mathrm{L} \mathrm{according}$ to the measurements in normal myocardium.

cardiac ischemia/reperfusion [7]. These results support our observations in this study and highlight the fact that MMP-9 is primarily regulated at the post-translational level. Furthermore, the fact that MMP-9 gene levels do not change at day 7 post-MI also suggest that MMP-9 should be evaluated at the protein level.

There is limited data available to construct suitable functions of $M\left(T_{\beta}\right), F_{g}\left(T_{\beta}\right), F_{c}\left(T_{\beta}\right)$, and $F_{c}(c)$. Wahl et al presented a set of in vitro data on monocyte chemotaxis induced by TGF- $\beta$ with concentration ranges from 0.05 $\mathrm{pg} / \mathrm{mL}$ to $10 \mathrm{pg} / \mathrm{mL}$ [17]. Their experiments also provided production of fibroblast growth activity induced with TGF- $\beta$ concentration range from $10 \mathrm{pg} / \mathrm{mL}$ to 10 $\mathrm{ng} / \mathrm{mL}$. These data were used in this study to construct the functions of $M\left(T_{\beta}\right)$ and $F_{g}\left(T_{\beta}\right)$. Roberts et al have presented a set of data on in vitro collagen formation stimulated by TGF- $\beta$ with the concentration range from $0.0825 \mathrm{pg} / \mathrm{mL}$ to $2.5 \mathrm{pg} / \mathrm{mL}$ [23]. Ignotz and Massague have examined the effects of TGF- $\beta$ on collagenases in chick embryo fibroblasts stimulated by TGF- $\beta$ at a concentration range of $1.25 \mathrm{ng} / \mathrm{mL}$ to $25 \mathrm{ng} / \mathrm{mL}$ [41]. We have done experiments to quantify the ECM production of cardiac fibroblast stimulated with TGF $-\beta(10 \mathrm{ng} / \mathrm{mL})$. These experimental data were used to build and justify the function, $F_{c}\left(T_{\beta}\right)$. Loftis and colleagues have studied effects of collagen density on cardiac fibroblast behavior and showed elevated fibroblast activities stimulated with higher collagen concentrations $(750 \mu \mathrm{g} / \mathrm{mL}-1250 \mu \mathrm{g} /$ $\mathrm{mL}$ ) [52]. Wu and colleagues showed that propeptides at lower levels caused about $80 \%$ decrease in collagen synthesis compared to control [53]. In this study, we used an in silico function $F_{c}(c)$ provided by Waugh and colleagues $[27,28]$. These experiments were done by different groups with different conditions and the in vitro experiments might not reflect the in vivo interactions. In addition, we established these functions using polynomial interpolation. It's likely that these functions are not the optimal forms to describe the in vivo interactions; however, they provide us a baseline for further study.

Our computational results demonstrated that altering the strength of TGF- $\beta_{1}$ altered LV remodeling outcomes. Elevated TGF- $\beta_{1}$ levels at the early stage (day 3 post-MI) led to elevated macrophage density and MMP9 levels, decreased fibroblast secretion of collagen and collagen deposition, and thereby, prolonged the progression of remodeling. Wetzler and colleagues have shown that the prolonged persistence of macrophages at the late phase (after day 7 post-MI) impairs the wound healing process [54]. It has also been shown that elevated TGF- $\beta_{1}$ levels delays wound healing post-MI $[55,56]$. 
Our simulation results are in agreement with these previously published studies.

Simulations of different TGF- $\beta_{1}$ strengths also shed light on the regulation scheme of ECM construction and destruction. For ECM construction regulation, active TGF- $\beta_{1}$ stimulated fibroblast proliferation and collagen secretion, which increased the crowding effect. The increased crowding coefficient ramped down fibroblast proliferation and TGF- $\beta_{1}$ secretion (negative feedback), which slowed down the stimulus for monocytes to migrate into the infarct region. The decrease of monocytes number led to less macrophage infiltration, which then reduced the crowding coefficient. Meanwhile, reduced macrophages lead to less TGF- $\beta_{1}$ secretion by macrophage, which further slowed down collagen synthesis. For collagen destruction regulation, TGF- $\beta_{1}$ induced macrophage infiltration, which lead to elevated MMP-9 secretion, elevated collagen degradation, and thereby reduced crowding coefficients. Smaller crowding coefficients lead to elevated fibroblast proliferation and collagen secretion. Notably, there are two types of negative feedback schemes in the mathematical model: degradation (apoptosis or emigration) rates associated with proteins (cells) and the crowding effects. Degradation rates are constants and determine how fast the proteins (cells) can respond to stimuli. Crowding effects are time varying impacts imposed by the environment. Through these regulation schemes, a dynamic balance of collagen construction and destruction can be maintained to generate a stable scar. Furthermore, profiles of crowding effects elucidated the transition from the normal LV to scar tissue with respect to cell types and collagen concentrations (Figure 3).

It is worth mentioning that there exist biological negative feedbacks in our mathematical model. For macrophage density regulation, there was a positive feedback loop containing macrophage and TGF- $\beta_{1}$ : TGF- $\beta_{1}$ stimulated monocytes migration, leading to macrophage infiltration; macrophages secreted TGF- $\beta_{1}$ which might attract more macrophages to the infarct site. We observed elevated macrophage density and MMP-9 concentrations corresponding to increased TGF- $\beta_{1}$ levels (Figure 5). This positive feedback loop was inhibited by emigration of macrophages and degradation of TGF- $\beta_{1}$. In addition, Wahl et al pointed out that the monocyte chemotactic activity increased in response to low concentrations of TGF- $\beta_{1}$ stimuli, while the chemotactic activity decreased in response to higher concentrations of TGF- $\beta_{1}$ [17]. Therefore, as TGF- $\beta_{1}$ levels continuously increased, infiltration speed of macrophages decreased as shown in figure $2\left(\mathrm{M}\left(\mathrm{T}_{\beta}\right)\right)$, suggesting a secondary biological inhibition scheme of the TGF- $\beta_{1}-$ macrophage positive feedback loop.
There are a few limitations of the mathematical model that resulted to a large degree from the model assumptions. More research is needed to address these limitations and further enhance the models. First, our model calls for accurate determination of MMP-9 activation and inhibition functions. Complete time-course measurements of TIMP-1 and the other three TIMPs (for MMP-9 inhibition) and MMP-3 (for MMP-9 activation) would provide additional details on the regulators of MMP-9 function. Second, the large differences between simulation results and experimental measurement of MMP-9 concentrations before day 4 post-MI in Figure 4 is likely due to the effect of neutrophils, an early source of MMP-9, indicating the need to investigate the role of neutrophils in the early stage (days 1-5) post-MI [7]. This inconsistency of the simulated MMP-9 concentrations and measurements from experimental results is one of the approaches for us to employ more biomarkers and key factors in model development. Third, Interleukin IL-1, IL-6, IL-10, and tumor necrosis factor$\alpha$ profiles need to be included to better study macrophage activation phenotypes [57]. Fourth, the effects of other chemoattractants on monocyte migration on the LV remodeling need further investigation. The predicted fibroblast density at days 14-30 post-MI was lower than experimental measurements. This might be caused by assumption 2, that the increase of fibroblast numbers post-MI was contributed solely by proliferation of local cells. We will investigate the migration rates of fibroblasts in the future to refine our mathematical model. Regardless of the above limitations, we were able to use our model to compute the progression of macrophages, fibroblasts, and collagen density, MMP-9 and TGF- $\beta_{1}$ concentrations post-MI.

This systems biology study for LV remodeling can be expanded to include proteomics and cardiac functions in future studies. We employed plasma data in this study since plasma proteins reflect the process of LV remodeling and plasma data are more directly translatable to the clinic. However, we are well aware that measuring tissue protein levels will provide a more direct evaluation of LV remodeling. Further investigation on the ECM proteomics in cardiac samples has been planned in our future research to establish a more complete mathematical model for LV remodeling. Though it is beyond the scope of the current paper, we have previously reported some data on cardiac function [58-60] and our future study will integrate cardiac function into the mathematical model.

The computational model for post-MI LV remodeling developed here illustrated the dynamic interactions among critical factors in LV remodeling. This is the first mathematical model focusing on the protein and cellular interactions post-MI. Thus, this model provides a strong 
foundation for future studies to build a more comprehensive model that takes into account a more complete set of parameters. The model also provides a tool to guide experimental designs by identifying candidate factors to intervene, the proper intervention time, and doses for effective interventions to achieve the most beneficial outcomes. As an example, we have shown the effects of MMP-9 intervention time and doses on LV remodeling outcomes in this study. Though this model was established based on in vitro data and in vivo data from mice, the modeling approach can be used to develop models for other scenarios such as the LV remodeling of human $\mathrm{MI}$ and LV remodeling under reperfusion conditions.

\section{Conclusions}

In conclusion, we developed a set of differential equations to quantitatively model the dynamic interactions and temporal changes of the key components identified from our experimental results. Predictions of the mathematical model fell well within experimental measurements, particularly with regard to macrophage infiltration and matrix remodeling. This mathematical model provides a powerful tool to better understand how the dynamic balance between ECM construction and ECM destruction influences LV remodeling outcomes.

\section{Methods}

\section{Mice}

All animal procedures were conducted in accordance with the Guide for the Care and Use of Laboratory Animals (National Research Council, 1996) and were approved by the Institutional Animal Care and Use Committee at the University of Texas Health Science Center at San Antonio. Male C57BL/6J wild type adult mice $(\mathrm{n}=13)$ at age $8.0 \pm 0.5$ months were used. One group $(\mathrm{n}=6)$ served as unoperated controls, while the other group $(\mathrm{n}=7)$ underwent coronary artery ligation for 7 days as described previously [9] and were sacrificed at day 7 post-myocardial infarction.

\section{In Vivo Procedures}

Blood was collected from the jugular vein and placed in a heparinized tube for plasma collection. Tissue was collected for the gene array analysis as described previously [9].

\section{Microarray and Plasma Analysis}

Total RNA was isolated using the TRIzol plus Total RNA purification kit (Invitrogen). The $\mathrm{RT}^{2}$ qPCR Primer Array for Extracellular Matrix and Adhesion Molecules (SuperArray catalog APMM-013A) was used for the gene array. Results were analyzed based on the
$\Delta \Delta \mathrm{Ct}$ method with normalization of raw data to the GAPDH housekeeper gene. Data are presented as average $2^{-\Delta \mathrm{CT}}$ levels.

For the fibroblast ECM microarray analysis, cardiac fibroblasts were isolated from adult C57BL/6J mice and stimulated with or without $10 \mathrm{ng} / \mathrm{ml} \mathrm{TGF}-\beta_{1}$ for 24 hours[61]. Plasma samples $(80 \mu \mathrm{L})$ were analyzed for 67 antigens using the quantitative immunoassay panel for mice provided by Rules Based Medicine in Austin, TX (http://www.rulesbasedmedicine.com).

\section{Statistical Analysis}

Control, remote, and infarct LV groups were analyzed by ANOVA, with the Bonferroni post hoc test. Control and MI plasma was analyzed by Students t-test. Unstimulated and TGF- $\beta_{1}$ stimulated fibroblast groups were analyzed by paired t-test. A p $<0.05$ was considered statistically significant.

\section{Acknowledgements}

The authors acknowledge grants support from NIH 1R03EB009496, NIH SC2HL101430, NSF 0649172, and AT\&T foundation (to YFJ), from NSF 0644646, and NSF 0602834 (to HCH), and NHLBI HHSN268201000036C (N01HV-00244), NIH R01 HL75360, AHA Grant-in-Aid 0855119F, and the Morrison Fund (to MLL)

\section{Author details}

${ }^{1}$ Department of Electrical and Computer Engineering, University of Texas at San Antonio, San Antonio, USA. ²Department of Mechanical Engineering, University of Texas at San Antonio, USA. ${ }^{3}$ Department of Medicine, University of Texas Health Science Center at San Antonio, San Antonio, USA.

\section{Authors' contributions}

YFJ, HCH, and MLL designed the research; JB, and QD performed animal experiments. YFJ performed the computational experiments. YFJ, $\mathrm{HCH}$, and MLL analyzed the results and wrote the manuscript. All authors have read and approved the final manuscript.

Received: 19 March 2010 Accepted: 5 May 2011 Published: 5 May 2011

\section{References}

1. Hellermann JP, Jacobsen SJ, Redfield MM, Reeder GS, Weston SA, Roger VL: Heart failure after myocardial infarction: clinical presentation and survival. Eur J Heart Fail 2005, 7:119-125.

2. Anavekar NS, McMurray JJV, Velazquez EJ, Solomon SD, Kober L, Rouleau JL, White HD, Nordlander R, Maggioni A, Dickstein K, et al: Relation between Renal Dysfunction and Cardiovascular Outcomes after Myocardial Infarction. N Engl J Med 2004, 351:1285-1295.

3. Cohn JN, Ferrari R, Sharpe N: Cardiac remodeling-concepts and clinical implications: a consensus paper from an international forum on cardiac remodeling. Behalf of an International Forum on Cardiac Remodeling. J Am Coll Cardiol 2000, 35:569-582.

4. Whittaker P: Collagen and ventricular remodeling after acute myocardial infarction: concepts and hypotheses. Basic Res Cardiol 1997, 92:79-81.

5. Zhang M, Shah MA: Role of reactive oxygen species in myocardial remodeling. Current Heart Failure Reports 2007, 4:26-30.

6. Rumberger JA: Ventricular Dilatation and Remodeling After Myocardial Infarction. Mayo Clin Proc 1994, 69:664-674.

7. Lindsey M, Wedin K, Brown MD, Keller C, Evans AJ, Smolen J, Burns AR, Rossen RD, Michael L, Entman M: Matrix-Dependent Mechanism of Neutrophil-Mediated Release and Activation of Matrix Metalloproteinase 9 in Myocardial Ischemia/Reperfusion. Circulation 2001, 103:2181-2187.

8. Rohde LE, Ducharme A, Arroyo LH, Aikawa M, Sukhova GH, Lopez-Anaya A, McClure KF, Mitchell PG, Libby P, Lee RT: Matrix metalloproteinase 
inhibition attenuates early left ventricular enlargement after experimental myocardial infarction in mice. Circulation 1999, 15:3063-3070.

9. Lindsey ML, Escobar GP, Dobrucki LW, Goshorn DK, Bouges S, Mingoia JT, McClister DM Jr, Su H, Gannon J, MacGillivray C, et al: Matrix metalloproteinase- 9 gene deletion facilitates angiogenesis after myocardial infarction. Am J Physiol Heart Circ Physiol 2006, 290:H232-239.

10. Webb CS, Bonnema DD, Ahmed SH, Leonardi AH, McClure CD, Clark LL, Stroud RE, Corn WC, Finklea L, Zile MR, Spinale FG: Specific Temporal Profile of Matrix Metalloproteinase Release Occurs in Patients After Myocardial Infarction: Relation to Left Ventricular Remodeling. Circulation 2006, 114:1020-1027.

11. Vanhoutte $D$, Schellings $M$, Pinto $Y$, Heymans $S$ : Relevance of matrix metalloproteinases and their inhibitors after myocardial infarction: $A$ temporal and spatial window. Cardiovasc Res 2006, 69:604-613.

12. Yang F, Liu YH, Yang XP, Xu J, Kapke A, Carretero OA: Myocardial infarction and cardiac remodelling in mice. Exp Physiol 2002, 87:547-555.

13. N Ashizawa KG, Do YS, Nunohiro T, Giachelli CM, Meehan WP, Tuan TL, Hsueh WA: Osteopontin is produced by rat cardiac fibroblasts and mediates $\mathrm{A}(\mathrm{II})$-induced DNA synthesis and collagen gel contraction. $J$ Clin Invest 1996, 98:2218-2227.

14. Lenga Y, Koh A, Perera AS, McCulloch CA, Sodek J, Zohar R: Osteopontin Expression Is Required for Myofibroblast Differentiation. Circ Res 2008, 102:319-327.

15. Zahradka P: Novel Role for Osteopontin in Cardiac Fibrosis. Circ Res 2008, 102:270-272.

16. Borg TK, Markwald R: Periostin: More Than Just an Adhesion Molecule. Circ Res 2007, 101:230-231.

17. Wahl SM, Hunt DA, Wakefield LM, McCartney-Francis N, Wahl LM, Roberts AB, Sporn MB: Transforming growth factor type beta induces monocyte chemotaxis and growth factor production. Proceedings of the National Academy of Sciences of the United States of America 1987, 84:5788-5792.

18. Krause SW, Rehli M, Kreutz M, Schwarzfischer L, Paulauskis JD, Andreesen R: Differential screening identifies genetic markers of monocyte to macrophage maturation. J Leuko Biol 1996, 60:510-545.

19. Burke B LC: The Macrophage. 2 edition. Oxford: Oxford University Press; 2002.

20. Quan TE, Cowper S, Wu SP, Bockenstedt LK, Bucala R: Circulating fibrocytes: collagen-secreting cells of the peripheral blood. The International Journal of Biochemistry \& Cell Biology 2004, 36:598-606.

21. Yehualaeshet T, O'Connor R, Green-Johnson J, Mai S, Silverstein Roy, Murphy-Ullrich JE, Khalil N: Activation of Rat Alveolar MacrophageDerived Latent Transforming Growth Factor $\beta-1$ by Plasmin Requires Interaction with Thrombospondin-1 and its Cell Surface Receptor, CD36. Am J Pathol 1999, 155:841-851.

22. Khali N, Whitman C, Zuo L, Danielpour D, Greenberg A: Regulation of alveolar macrophage transforming growth factor-beta secretion by corticosteroids in bleomycin-induced pulmonary inflammation in the rat. JClin Invest 1993, 92:1812-1818.

23. Roberts AB, Sporn MB, Assoian RK, Smith JM, Roche NS, Wakefield LM, Heine UI, Liotta LA, Falanga V, Kehrl JH: Transforming growth factor type beta: rapid induction of fibrosis and angiogenesis in vivo and stimulation of collagen formation in vitro. Proceedings of the National Academy of Sciences of the United States of America 1986, 83:4167-4171.

24. Ignotz RA, Massagué J: Transforming growth factor-beta stimulates the expression of fibronectin and collagen and their incorporation into the extracellular matrix. Journal of Biological Chemistry 1986, 261:4337-4345.

25. Leroy EC: Increased Collagen Synthesis by Scleroderma Skin Fibroblasts In Vitro: a possibledefect in the regulation or activation of the scleroderma fibroblast. J Clin Invest 1974, 54:880-889.

26. Naugle JE OE, Zhang X, Mase SE, Pilati CF, Maron MB, Folkesson HG, Horne WI, Doane KJ, Meszaros JG: Type VI collagen induces cardiac myofibroblast differentiation: implications for postinfarction remodeling. Am J Physiol Heart Circ Physiol 2006, 290:H323-330.

27. Waugh H, Sherratt J: Macrophage Dynamics in Diabetic Wound Dealing. Bulletin of Mathematical Biology 2006, 68:197-207.

28. Helen V, Waugh JAS: Modeling the effects of treating diabetic wounds with engineered skin substitutes. Wound Repair and Regeneration 2007, 15:556-565.
29. Bellingan GJ, Caldwell H, Howie SE, Dransfield I, Haslett C: In vivo fate of the inflammatory macrophage during the resolution of inflammation: inflammatory macrophages do not die locally, but emigrate to the draining lymph nodes. J Immunol 1996, 157:2577-2585.

30. Olsen $L$, Sherratt JA, Maini PK: A mathematical model for fibroproliferative wound healing disorders. Bull Math Biol 1996, 58:787-808.

31. Munoz-Alicea RN-MP, Marcano-Velazquez M: A mathematical model for macrophage, T-cell and mycobacterium tuberculosis interactions. Book A mathematical model for macrophage, T-cell and mycobacterium tuberculosis interactions City: University of Puerto Rico; 1999, Editor ed.^eds.

32. Banerjee I, Fuseler JW, Price RL, Borg TK, Baudino TA: Determination of cell types and numbers during cardiac development in the neonatal and adult rat and mouse. Am J Physiol Heart Circ Physiol 2007, 293:H1883-1891.

33. Darby IA, Bisucci T, Hewitson TD, MacLellan DG: Apoptosis is increased in a model of diabetes-impaired wound healing in genetically diabetic mice. The International Journal of Biochemistry \& Cell Biology 1997, 29:191-200.

34. Huang M, Sharma S, Zhu L, Keane M, Luo J, Zhang L, Burdick M, Lin Y, Dohadwala M, Gardner B, et al: IL-7 inhibits fibroblast TGF-beta production and signaling in pulmonary fibrosis. J Clin Invest 2002, 109:931-937.

35. Cobbold CA, Sherratt JA: Mathematical Modelling of Nitric Oxide Activity in Wound Healing can explain Keloid and Hypertrophic Scarring. Journal of Theoretical Biology 2000, 204:257-288.

36. Zhang $H$, Ahmad M, Gronowicz G: Effects of transforming growth factorbeta 1 (TGF-[beta]1) on in vitro mineralization of human osteoblasts on implant materials. Biomaterials 2003, 24:2013-2020.

37. Vandervelde $\mathrm{S}$, van Luyn MJA, Rozenbaum MH, Petersen AH, Tio RA, Harmsen MC: Stem cell-related cardiac gene expression early after murine myocardial infarction. Cardiovasc Res 2007, 73:783-793.

38. Sun Y, Weber KT: Cardiac remodeling by fibrous tissue: role of local factors and circulating hormones. Ann Med 1998, 30:3-8.

39. Czarkowska-P ${ }_{3}$ czek B, Przybylski J, Marciniak A, Pawłowska M, Juskowa J, Foroncewicz B, Mucha K: Proteolytic Enzymes Activities in Patients After Myocardial Infarction Correlate with Serum Concentration of TGF- $\beta$. Inflammation 2004, 28:279-284.

40. Schaan B, Quadros A, Sarmento-Leite R, De Lucca G, Bender A, Bertoluci M: 'Correction:' Serum transforming growth factor beta-1 (TGF-beta-1) levels in diabetic patients are not associated with pre-existent coronary artery disease. Cardiovascular Diabetology 2007, 6:19.

41. Ignotz R, Massague J: Transforming growth factor-beta stimulates the expression of fibronectin and collagen and their incorporation into the extracellular matrix. J Biol Chem 1986, 261:4337-4345.

42. Karagiannis ED, Popel AS: A Theoretical Model of Type I Collagen Proteolysis by Matrix Metalloproteinase (MMP) 2 and Membrane Type 1 MMP in the Presence of Tissue Inhibitor of Metalloproteinase 2. J Biol Chem 2004, 279:39105-39114.

43. Vempati P, Karagiannis ED, Popel AS: A Biochemical Model of Matrix Metalloproteinase 9 Activation and Inhibition. J Biol Chem 2007, 282:37585-37596.

44. Fang L, Gao XM, Moore XL, Kiriazis H, Su Y, Ming Z, Lim YL, Dart AM, Du XJ: Differences in inflammation, MMP activation and collagen damage account for gender difference in murine cardiac rupture following myocardial infarction. Journal of Molecular and Cellular Cardiology 2007, 43:535-544.

45. Kelly D, Cockerill G, Ng LL, Thompson M, Khan S, Samani NJ, Squire IB: Plasma matrix metalloproteinase-9 and left ventricular remodelling after acute myocardial infarction in man: a prospective cohort study. Eur Heart J 2007, 28:711-718

46. Kaden JJ, Dempfle CE, Sueselbeck T, Brueckmann M, Poerner TC, Haghi D, Haase KK, Borggrefe M: Time-Dependent Changes in the Plasma Concentration of Matrix Metalloproteinase 9 after Acute Myocardial Infarction. Cardiology 2003, 99:140-144.

47. Sumitra M, Manikandan P, Nayeem M, Manohar BM, Lokanadam B, Vairamuthu S, Subramaniam S, Puvanakrishnan R: Time course studies on the initiation of complement activation in acute myocardial infarction induced by coronary artery ligation in rats. Molecular and cellular biochemistry 2005, 268:149-158.

48. Xiao-Ming G, Ziqiu M, Yidan S, Lu F, Helen K, Qi X, Anthony MD, XiaoJun D: Infarct size and post-infarct inflammation determine the risk of cardiac rupture in mice. International journal of cardiology 2010, 143:20-28. 
49. Gao XM, Xu Q, Kiriazis H, Dart AM, Du XJ: Mouse model of post-infarct ventricular rupture: time course, strain- and gender-dependency, tensile strength, and histopathology. Cardiovascular Research 2005, 65:469-477.

50. Kjeldsen L, Sengelov H, Lollike K, Nielsen MH, Borregaard N: Isolation and Characterization of Gelatinase Granules from Human Neutrophils. Blood 1994, 83:1640-1649.

51. Cleutjens JP, Kandala JC, Guarda E, Guntaka RV, Weber KT: Regulation of collagen degradation in the rat myocardium after infarction. Journal of molecular and cellular cardiology 1995, 27:1281-1292.

52. Loftis MJ, Sexton D, Carver W: Effects of collagen density on cardiac fibroblast behavior and gene expression. Journal of Cellular Physiology 2003, 196:504-511.

53. Wu CH, Donovan $\mathrm{CB}$, Wu GY: Evidence for pretranslational regulation of collagen synthesis by procollagen propeptides. Journal of Biological Chemistry 1986, 261:10482-10484.

54. Wetzler C, Kampfer H, Stallmeyer B, Pfeilschifter J, Frank S: Large and Sustained Induction of Chemokines during Impaired Wound Healing in the Genetically Diabetic Mouse: Prolonged Persistence of Neutrophils and Macrophages during the Late Phase of Repair. 2000, 115:245-253.

55. Ertl G, Frantz S: Healing after myocardial infarction. Cardiovasc Res 2005, 66:22-32.

56. Nakajima H, Nakajima HO, Salcher O, Dittie AS, Dembowsky K, Jing S, Field LJ: Atrial but Not Ventricular Fibrosis in Mice Expressing a Mutant Transforming Growth Factor-\{beta\}1 Transgene in the Heart. Circ Res 2000, 86:571-579.

57. Day J, Friedman A, Schlesinger LS: Modeling the immune rheostat of macrophages in the lung in response to infection. Proceedings of the National Academy of Sciences 2009, 106(27):11246-51.

58. Lin J, Lopez EF, Jin Y, Van Remmen H, Bauch T, Han HC, Lindsey ML: Agerelated cardiac muscle sarcopenia: Combining experimental and mathematical modeling to identify mechanisms. Exp Gerontol 2008, 43:296-306.

59. Lindsey ML, Goshorn DK, Squires CE, Escobar GP, Hendrick JW, Mingoia JT, Sweterlitsch SE, Spinale FG: Age-dependent changes in myocardial matrix metalloproteinase/tissue inhibitor of metalloproteinase profiles and fibroblast function. Cardiovasc Res 2005, 66:410-419.

60. Zamilpa R, Lopez EF, Chiao YA, Dai Q, Escobar GP, Hakala K, Weintraub ST, Lindsey ML: Proteomic analysis identifies in vivo candidate matrix metalloproteinase- 9 substrates in the left ventricle post-myocardial infarction. PROTEOMICS 2010, 10:2214-2223.

61. Squires CE, Escobar GP, Payne JF, Leonardi RA, Goshorn DK, Sheats NJ, Mains IM, Mingoia JT, Flack EC, Lindsey ML: Altered fibroblast function following myocardial infarction. Journal of Molecular and Cellular Cardiology 2005, 39:699-707.

62. Johan $\mathrm{D}$, Heilborn $\mathrm{KBAH}$ : Inhibited proliferation of fibroblasts derived from chronic diabetic wounds and normal dermal fibroblasts treated with high glucose is associated with increased formation of L-lactate. Wound Repair and Regeneration 1998, 6:135-141.

63. Loredana Moro AAAJLYPAdSAEMMG: Loss of BRCA2 promotes prostate cancer cell invasion through up-regulation of matrix metalloproteinase9. Cancer Science 2008, 99:553-563.

64. Eberhardt W, Akool ELS, Rebhan J, Frank S, Beck KF, Franzen R, Hamada FMA, Pfeilschifter J: Inhibition of cytokine-induced MMP-9 expression by PPARalpha agpnists is indirect and is due to a nomediated reduction of mRNA stability. J Biol Chem 2002, M202008200.

65. Eberhardt W, Akool ELS, Rebhan J, Frank S, Beck KF, Franzen R, Hamada FMA, Pfeilschifter J: Inhibition of Cytokine-induced Matrix Metalloproteinase 9 Expression by Peroxisome Proliferator-activated Receptor alpha Agonists Is Indirect and Due to a NO-mediated Reduction of mRNA Stability. J Biol Chem 2002, 277:33518-33528.

66. Monaco S, Sparano V, Gioia M, Sbardella D, Pierro DD, Marini S, Coletta M: Enzymatic processing of collagen IV by MMP-2 (gelatinase A) affects neutrophil migration and it is modulated by extracatalytic domains. Protein Sci 2006, 15:2805-2815.

67. Iris Metzmacher PR, Abel Martin, Friess Wolfgang: In vitro binding of matrix metalloproteinase-2 (MMP-2), MMP-9, and bacterial collagenase on collagenous wound dressings. Wound Repair and Regeneration 2007, 15:549-555.

68. Atkins P: Physical Chemistry for the Life Sciences Oxford, Oxford University Press; 2006. doi:10.1186/1752-0509-5-60

Cite this article as: Jin et al:: Combining experimental and mathematical modeling to reveal mechanisms of macrophage-dependent left ventricular remodeling. BMC Systems Biology 2011 5:60.

\section{Submit your next manuscript to BioMed Central and take full advantage of:}

- Convenient online submission

- Thorough peer review

- No space constraints or color figure charges

- Immediate publication on acceptance

- Inclusion in PubMed, CAS, Scopus and Google Scholar

- Research which is freely available for redistribution

Submit your manuscript at www.biomedcentral.com/submit
Biomed Central 